\title{
Církev online. Římskokatolická církev a sociální média v České republice ${ }^{1}$ Jakub Havlíček
}

\begin{abstract}
Abstrakt
Stat' se zabývá prezentací katolické církve na internetu, zejména na sociálních sítích. Shrnuje oficiální stanoviska církve k internetu a zaměřuje se na stav využívání sociálních sítí církví s dưrazem na české prostředí. Řeší otázku interpretace problematiky z hlediska sociálně vědního studia náboženství. Metodologicky stat' vychází z kvalitativní deskriptivní analýzy primárních zdrojů a z kvantitativní analýzy stránek na sociálních sítích. Z emického hlediska plní prezentace na sociálních sítích pro církev funkce informační, evangelizační a pastorační. Využití sociálních sítí je spojováno s novou evangelizací. Z etického hlediska interpretuje text zkoumanou problematiku ve vztahu ke koncepci sekularizace na úrovních individuální, societální a organizační. Církev pomocí prezentací na sociálních sítích reaguje na individualizaci a privatizaci náboženství, prezentace na sociálních sítích církvi slouží i k nastolování mediální a veřejné agendy a k formování, udržování a šíření náboženské paměti. Lze pozorovat i změny v organizačním uspořádání církevní správy, jimiž církev reaguje na sociokulturní změny v moderních společnostech.
\end{abstract}

Klíčová slova: Církev římskokatolická, internet, sociální média, Facebook, nová evangelizace, sekularizace, nastolování agendy, náboženská pamět’

\section{Úvodem}

Internet se stává součástí náboženského života a dává vzniknout online náboženství, tedy náboženské zkušenosti a náboženské praxi na internetu ${ }^{2} \mathrm{v}$ řadě podob, jejichž různorodost pravděpodobně do budoucna poroste. ${ }^{3}$ Tato studie se však zaměřuje spíše na náboženství online, chápané $\mathrm{v}$ širokém slova smyslu jako informace o náboženství, které jsou internetem zprostředkovány. ${ }^{4}$ Církve a náboženské společnosti reagují a přizpůsobují se novým podmínkám „digitální komunikační revoluce ${ }^{\text {" } 5}$ která církve vede k potřebě komunikovat novými způsoby, za použití nových

1 Zpracování a vydání publikace bylo umožněno díky finanční podpoře Filozofické fakulty Univerzity Palackého v Olomouci v roce 2018 z Fondu pro podporu vědecké činnosti (grant FPVČ 2015/03: Re-produkce vědění o náboženství a vzdělávací systém v moderní české společnosti).

2 Rosalind I. J. HACKETT, Religion and the Internet, Diogenes 3/2006, s. 68.

3 Srov. Brenda E. BRASHER, Give me that online religion, San Francisco: Jossey-Bass Inc., Wiley, 2001, s. 11.

HACKETT, Religion..., s. 68.

Christian SMITH, Soul Searching. The Religious and Spiritual Lives of American Teenagers, Oxford: Oxford University Press, 2005, s. 180. 
technologií. Zaměřím se zejména na internetová sociální média využívaná církvemi na př́ikladu Církve římskokatolické, ${ }^{6}$ se zvláštním zřetelem k českému prostředí.

Internet a online sociální sítě či sociální média ${ }^{7}$ se staly běžnou součástí života v současné společnosti. Podle údajů Českého statistického úřadu za rok 2016 používalo internet $76,5 \%$ jednotlivců starších 16 let, přičemž denně jej používalo 60,3 \% jednotlivců. ${ }^{8}$ Zároveň podle téhož šetření používalo internetové sociální sítě 41,4 \% jednotlivců starších 16 let a ve věkové skupině 16-24 let to bylo dokonce $91,4 \%$ jednotlivců. ${ }^{9}$ Pro činitele působící ve veřejném prostoru, $\mathrm{k}$ nimž řadím i církve a náboženské společnosti s jejich představiteli, se přítomnost na internetu a prezentace pomocí sociálních sítí stávají téměř nezbytností. Navíc data o využívání internetových sociálních sítí mladými ukazují, že budou-li církve chtít oslovit právě tuto věkovou skupinu, nemohou prezentaci prostřednictvím online sociálních médií opominout.

Základním cílem této stati je odpovědět na otázku, jak se církev prezentuje prostřednictvím internetu, zejména na online sociálních sítích. Zaměřím se nejprve krátce na internetovou prezentaci Svatého stolce, s důrazem na sociální média a postoje k prezentaci na internetu a sociálních sítích, které zaujímá Svatý stolec a kuriální instituce. Dále se zaměřím na postoje a stanoviska k působení na sociálních sítích, které veřejně prezentuje sama česká katolická církev a její představitelé. Hlavním záměrem je však poskytnout přehled současného stavu ${ }^{10}$ prezentace nejvyšších institucí české církevní správy a představitelů těchto institucí na online sociálních sítích, jejíž přehled je jádrem této studie. V poslední části budu hledat ty koncepce religionistiky jako sociálně vědního zkoumání náboženství, které lze aplikovat na současnou situaci prezentace katolické církve na sociálních sítích.

\section{Teoreticko-metodologický rámec}

Po metodologické stránce využívám kombinaci kvalitativních a kvantitativních metod. Část věnovaná stanoviskům církve a jejích představitelů k problematice prezentace na internetu a zvláště na online sociálních sítích vychází z kvalitativní deskriptivní analýzy primárních zdrojů, zejména oficiálních internetových stránek institucí katolické církve v zahraničí i u nás, a také z analýzy sekundární literatury k této problematice. Budu přitom využívat primárně vyjádření a dokumenty, které církev k problematice prezentuje prostřednictvím samotných internetových médií, zejména na svých oficiálních webových platformách. Přehled stavu prezentace církve na sociálních sítích v českém prostředí je založen na kvantitativní analýze stránek dostupných na sociálních sítích Facebook a Twitter. Ke stanovení okruhu stránek, které zahrnuji do přehledu, používám

Jak ukazují výzkumy týkající se využívání internetových sociálních sítí v českém prostředí (viz pozn. 8, 9), jsou tato média populární zejména mezi mládeží - to představuje pro církve výzvu a zároveň prostor pro oslovení právě této skupiny uživatelů internetu. Jak ukazuje přehled stránek, kterými se katolická církev prezentuje na Facebooku, řada z nich je zaměřena na mládež (viz dále v textu). V textu budu dále pro Církev římskokatolickou užívat pojmy katolická církev či jen církev.

7 Pojmy „online/internetová sociální sít“ a „online/internetové sociální médium“ se v běžném i odborném diskurzu často používají jako volně zaměnitelné. Považuji za vhodné upozornit na možnost rozlišit jejich významový obsah. U pojmu „internetová sociální sít“ lze vyjít ze sociologického chápání sociální sítě jako souboru vztahů či vzájemných vlivů mezi prvky souboru, jednotlivci či skupinami jednotlivců, které existují v prostředí internetu. „Internetové sociální médium“ je možné chápat jako interaktivní internetovou platformu, která existenci online sociální sítě umožňuje (např. Facebook, Twitter, LinkedIn, atd.) a je v podstatě nositelem sociální sítě v prostředí internetu, platformou umožňující existenci vztahů mezi prvky sítě a komunikaci mezi těmito prvky. $V$ tomto textu se však neodchyluji od běžné praxe a používám oba pojmy jako synonymní ve významu internetové platformy, sociálního média i sociální sítě $\mathrm{v}$ internetovém prostředí.

8 C Český statistický úřad, Informační společnost v číslech. Česká republika a EU. 2017 (on-line), s. 42, dostupné na: https://www.czso.cz/ documents/10180/46014808/061004-17.pdf/26e123e0-1dde-49c3-89ce-85f7fb85c7d4?version=1.1, citováno dne 19. 1. 2018.

9 Tamtéž, s. 50.

10 Jedná se o př̌ehled stavu podle níže uvedených kritérií k měsíci lednu 2018, v němž vznikla hlavní část této stati. Srov. pozn. 75. 
publikovaná statistická data k využívání internetu a sociálních sítí. Poslední část, poskytující perspektivu religionistiky na otázku prezentace církve na sociálních sítích, je založena na přístupech z oblasti religionistiky, sociologie a mediálních studií.

Z koncepční perspektivy vycházím ze dvou základních hledisek: emického a etického, ${ }^{11} \mathrm{kdy}$ se pokouším o shrnutí postojů církve a jejích představitelů k prezentaci na online sociálních sítích a o shrnutí možností konceptualizace této problematiky z hlediska religionistiky. Nebudu se podrobně věnovat teologickým hlediskům problematiky, i když se těmto souvislostem není možné zcela vyhnout, zejména je-li jedním z mých témat emická perspektiva na problematiku využívání internetových sociálních sítí. Součástí odpovědi na otázky emického hlediska budou proto i některé teologické koncepty, jako např́klad tzv. nová evangelizace. Teologická rovina problematiky nicméně není teoretickým rámcem této studie. Protože je tento text založen na paradigmatu religionistiky jako sociálně vědního, mezioborově založeného, neteologického a hodnotově neutrálního zkoumání náboženství, vykládám teologickou rovinu jednoduše jako prostředek teologické legitimizace problematiky v církevním prostředí, aniž bych $\mathrm{k}$ této otázce zaujímal jakékoli hodnotící stanovisko. V souvislosti s religionistickou perspektivou, která představuje etickou rovinu zkoumání konkrétní problematiky, budu hledat ty teoretické a konceptualizační nástroje religionistiky jako sociální vědy, jež je možné použít při interpretaci užívání nových technologií církví, zejména pokud jde o prezentaci prostřednictvím internetových sociálních sítí.

Základním cílem statě je však podat přehled prezentace katolické církve na internetových sociálních sítích $\mathrm{v}$ českém prostředí. Není možné splnit takto komplexní cíl v rámci jediné statě, proto chci tento text pojmout jako první krok k jeho naplnění. Vzorek, který bude zahrnut do přehledu, je nejprve nutné přesněji vymezit.

Z internetových sociálních sítí v českém prostředí patří nejvýznamnější podíl síti Facebook, která, jak ukazují nedávné průzkumy, je z hlediska počtu uživatelů výrazně dominantní. Podle údajů publikovaných ve výzkumné zprávě agentury Focus vlastnilo v září roku 2016 profil na sociální síti Facebook $42 \%$ dospělé populace České republiky. ${ }^{12} \mathrm{~S}$ výrazným odstupem následují ostatní platformy, mezi nimiž lze uvést Google+, Youtube či Instagram: na těchto sítích mělo účet mezi 8-12\% populace, zatímco účet na Twitteru vlastnila podle tohoto průzkumu $4 \%$ dospělé populace. ${ }^{13}$ Jiné, novější údaje $\mathrm{k}$ podílu na trhu za jednotlivé měsíce od prosince 2016 do prosince $2017^{14}$ potvrzují zásadní postavení Facebooku, když uvádějí u této sítě podíl na trhu v rámci České republiky pro jednotlivé měsíce v rozmezí 53-74\%, zatímco podíly ostatních sociálních sítí se $\mathrm{v}$ tomto roce pohybují přibližně kolem $10 \%$. Samotná sociální sít Facebook udává pro reklamní sdělení šířená jejím prostřednictvím v rámci České republiky k lednu 2018 potenciální dopad až na 5300000 osob. ${ }^{15} \mathrm{Z}$ těchto důvodů se zaměřím na prezentaci církve prostřednictvím sociální

11 Jednoduše řečeno, emické hledisko představuje perspektivu aktérů, v tomto př́ípadě církve a jejích představitelů, etické hledisko je založeno na perspektivě objektivizující vědy, v tomto př́padě religionistiky jako mezioborově pojaté sociální vědy o náboženství. Emická a etická perspektiva patři k základním pojmům v kulturní antropologii. Pojmy jsou spojeny s antropologem a lingvistou Kennethem L. Pikem, který je vymezil v roce 1967 (Alan BARNARD - Jonathan SPENCER, ed., Encyclopedia of Social and Cultural Anthropology, London: Routledge, 2002, s. 180-183). Uplatnění těchto konceptů v mém textu je založeno na využití kombinace kvalitativních a kvantitativních př́stupů ke zkoumanému tématu, kdy cílem je integrace informací získaných za použití různých metod za účelem zachycení více rozměrů a souvislostí zkoumaného fenoménu (srov. Sharlene HESSE-BIBER - R. Burke JOHNSON, ed., The Oxford Handbook of Multimethod and Mixed Methods Research Inquiry, Oxford: Oxford University Press, 2010, s. 576).

12 ๑ Focus, Uživatelé sociálních sítí v ČR (on-line), dostupné na http://www.focus-agency.cz/files/contentFiles/socialni-site-2016-cz.pdf, citováno dne 12. 12. 2017.

13 Tamtéž.

14 (c) StatCounter, Social Media Stats Czech Republic (on-line), dostupné na http://gs.statcounter.com/social-media-stats/all/czech-republ ic/\#monthly-201612-201712, citováno dne 18. 1. 2018. 
sítě Facebook. Pro účely srovnání uvádím údaje o počtu sledujících k některým stránkám na sociální síti Twitter, která poskytuje oficiální prezentační platformu Svatému stolci.

Nejen na samotném Facebooku, ale na českém internetu vůbec lze najít značné množství stránek, které se nějakým zpơsobem vztahují k církvi či ke katolictví, proto je nutné přesněji vymezit okruh těch stránek, kterými se budu dále zabývat - přehled prezentace církve na této sociální síti nelze pojmout jako vyčerpávající. Budu se věnovat pouze těm stránkám na sociální síti Facebook, které jsou oficiálními komunikačními a prezentačními platformami církve, jejích institucí, orgánů a jejich představitelů v České republice. Do přehledu zahrnu ty stránky, které jsou otevřenými komunikačními platformami a nejsou např́klad uzavřenými diskusními skupinami. Budu přitom vycházet z organizační struktury církevní správy a z důvodu omezení rozsahu se zaměřím na arcibiskupství a biskupství, na jejich představitele a na orgány církve na této nejvyšší správní úrovni, jejichž činnost je primárně směřována $\mathrm{k}$ českému prostředí, resp. vychází $\mathrm{z}$ českého prostředí. K nim řadím prezentaci České biskupské konference. ${ }^{16}$ Do přehledu zahrnuji také prezentaci Katolického týdeníku, protože jde o oficiální mediální platformu České a Moravské církevní provincie a bezesporu o významné komunikační médium církve s historickou tradicí, jehož majitelem je ČBK. ${ }^{17}$ Dalším církevním institucím a organizacím, řádům, vikariátům, děkanátům, farnostem, ani stránkám, které nejsou přímo začleněny do uvedených církevních institucí na úrovni arcibiskupství a biskupství, se nebudu podrobněji věnovat. Do přehledu nezahrnuji např́klad ani stránky organizace Charita Česká republika a jejích jednotlivých složek (diecézních či farních charit), nebot’ jde o samostatnou neziskovou organizaci zřizovanou ČBK a působící primárně v oblasti sociálních služeb. Nebudu se věnovat ani stránkám představitelů církve, které jsou spravovány jejich fanoušky, anebo církevní představitele či instituce parodují. ${ }^{18}$ Budu se zabývat pouze těmi stránkami, které jsou na Facebooku či Twitteru otevřeně označeny jako oficiální stránky institucí a představitelů církve v České republice, nebo jsou na tyto stránky umístěny odkazy na oficiálních webových portálech př́íslušných církevních institucí, pod něž stránky organizačně spadají. ${ }^{19}$ Posledními kritérii jsou počet sledujících a aktivita na stránce: v mém přehledu uvádím stránky, které mají k 19. lednu 2018 alespoň 200 sledujících a v období jednoho roku před datem 19. ledna 2018 je uveřejněn alespoň jeden př́spěvek.

\section{Církev, internet a online sociální sítě dnes}

Jak se v současné době staví k využívání internetu a online sociálních sítí Svatý stolec jako nejvyšší církevní instituce a jaká je nedávná historie využívání nových komunikačních technologií a internetu církví?

16 Dále ČBK.

17 Podle obchodního rejstř́iku je vydavatelem Katolického týdeníku stejnojmenná společnost s ručením omezeným, jejímž jediným společníkem je ČBK (@ MSpČR, Úplný výpis z obchodního rejstř́ku [on-line], dostupné na https:/or.justice.cz/ias/ui/rejstrik-firma. vysledky? subjektId=663730\&typ=UPLNY, citováno dne 19. 1. 2018).

18 Př́kladem „fanouškovské“ stránky může být facebooková stránka kardinála Dominika Duky, dostupná na adrese https://www.facebook. com/Dominik.Duka/ - podle informací na této stránce je provozována kardinálovými fanoušky a ke dni 19. ledna 2018 je volbou „Tohle se mi líbí označena 2348 uživateli, 2277 uživatelů stránku sleduje. Př́kladem parodické stránky s katolickou tematikou může být stránka Tisíckráte na adrese https://www.facebook.com/tisickrate/, která je ke stejnému datu označena volbou „Tohle se mi líbí“ 5895 uživateli a 6190 uživatelů tuto stránku sleduje. Podobné stránky představují možný směr další výzkumné práce.

19 Nezařadím tedy například stránku emeritního plzeňského biskupa Františka Radkovského, která je dostupná na adrese https://www. facebook.com/Mons.Frantisek.Radkovsky/. Stránka není označena jako ověřený či oficiální profil. Dále např. stránka Papežských misijních děl v České republice (dostupná na adrese https://www.facebook.com/PapezskaMisijniDila/) se vzhledem k profilu této organizace dostává na pomyslnou hranici splnění kritérií $\mathrm{k}$ zařazení do přehledu. Papežská misijní díla jsou primárně zaměřena na světové misie a jejich činnost zahrnuje mezinárodní projekty, působí však významně i př́mo v diecézích v České republice (např́ílad v oblasti pastorace dětí - viz Ivana HAJIČOVÁ, Analýza činnosti papežských misijních děl v České republice, diplomová práce, Praha: Univerzita Karlova, Katolická teologická fakulta, Katedra teologické etiky a spirituální teologie, 2013, s. 55) - vzhledem ke zvoleným kritériím nebyla stránka Papežských misijních děl do přehledu zařazena. 
Lze říci, že oficiálně Svatý stolec a jeho instituce zaujímají k prezentaci na internetu a sociálních sítích vstřícný postoj. $Z$ emického hlediska, tedy v samotném církevním prostředí, lze použití internetu spojit s koncepcí „nové evangelizace“ ${ }^{20}$ Pojem „nová evangelizace“ není užíván vždy ve zcela jednoznačném významu - ten se může do jisté míry lišit podle místních podmínek, ${ }^{21}$ avšak jeho základní význam je v církevním prostředí dán kontextem svého vzniku. Samotný pojem se objevuje v souvislosti s papežem Pavlem VI. a jeho apoštolskou exhortací Evangelii nuntiandi z roku $1975,{ }^{22}$ kde papež píše o „novém období evangelizace ${ }^{\text {“23 }}$ po 2 . vatikánském koncilu. Samotnou koncepci významně rozvíjí Jan Pavel II. ve své encyklice Redemptoris missio z roku 1990, ${ }^{24}$ v níž je pojem definován jednoznačně jako opětovná evangelizace či „,re-evangelizace“ těch, kteř́ „již obdrželi Kristovo poslání ${ }^{25}$ Nová evangelizace se týká zejména zemí se „starou křestanskou tradicí “ ${ }^{26} \mathrm{kde}$ je víra oslabena, případně se lidé už necítí být př́slušníky církve - v takových případech je třeba „re-evangelizace“, ${ }^{27}$ kterou dokument doporučuje provádět i za použití „audiovizuálních prostř̌edkư “, 28 zejména mezi mládeží. Benedikt XVI. dává svým apoštolským listem motu proprio $^{29} v$ roce 2010 koncepci nové evangelizace institucionální záštitu, když zřizuje Papežskou radu pro novou evangelizaci coby nové kuriální dikasterium..$^{30}$

V samotném církevním prostředí je nová evangelizace spojena s využíváním nových technologií a moderních komunikačních prostředků, tedy i internetu a internetových sociálních sítí, což dokládá např́íklad vyjádření kardinála Claudia $M$. Celliho, předsedy Papežské rady pro sdělovací prostředky. ${ }^{31}$ Kardinál Celli v rozhovoru z roku 2014 vysvětluje používání online sociálních sítí a nových médií vůbec jako snahu církve používat internet nikoli jako pouhý prostředek evangelizace, nýbrž evangelizovat „digitální kontinent“ doslova „zevnitř̌“ ${ }^{32}$ Kardinál Claudio M. Celli navštívil v roce 2013 Prahu a zpráva $z$ jeho návštěvy je zveřejněna na internetové stránce kardinála Dominika Duky. ${ }^{33}$ Zpráva vyzdvihuje potřebu aktivní účasti církve na sociálních sítích

20 Viz () John P. FOLEY, Dokument: Církev a internet (on-line), aktualizace dne 22. 2. 2002, dostupné na http://www.pastorace.cz/ tematicke-texty/dokument-cirkev-a-internet-papezska-rada-pro-hromadne-sdelovaci-prostredky-2222002, citováno dne 19. 1. 2018. Ke koncepci nové evangelizace a využívání nových médií církví srov. Ineke de FEIJTER, The Art of Dialogue. Religion, Communication and Global Media Culture, Berlin: LIT Verlag, 2007, s. 187; srov. také Ian LINDEN, Global Catholicism: Evangelization and a Networked Church, in: The New Evangelization: Faith, People, Context and Practice, ed. Paul GROGAN - Kim KIRSTEEN, London: Bloomsbury, 2015, s. 124.

21 Paul GROGAN - Kim KIRSTEEN, ed., The New Evangelization: Faith, People, Context and Practice, London: Bloomsbury, 2015, vii.

22 (c) PAULUS PP. VI, Evangelii nuntiandi. Apostolic exhortation of His Holiness pope Paul VI to the episcopate, to the clergy and to all the faithful of the entire world, 1975 (on-line), dostupné na http://w2.vatican.va/content/paul-vi/en/apost_exhortations/documents/hf_pvi_exh_19751208_evangelii-nuntiandi.html, citováno dne 18. 1. 2018.

23 Tamtéž, 2.

24 () IOANNES PAULUS PP. II, Redemptoris missio. On the permanent validity of the Church's missionary mandate, 1990 (on-line), aktualizace dne 27.6. 2015, dostupné na http://w2.vatican.va/content/john-paul-ii/en/encyclicals/documents/hf_jp-ii_enc_07121990_ redemptoris-missio.html, citováno dne 1.2. 2018.

25 Tamtéž, 30.

26 Tamtéž, 33.

27 Tamtéž

28 Tamtéž, 83.

29 Jde o reskript vydaný papežem „z vlastní pohnutky“ (motu proprio), bez podnětu třetí strany.

30 (C) BENEDICTUS PP. XVI, Apostolic letter in the form of motu proprio Ubicumque et semper of the supreme pontiff Benedict XVI establishing the pontifical council for promoting the new evangelization (on-line), dostupné na http://w2.vatican.va/content/benedictxvi/en/apost_letters/documents/hf_ben-xvi_apl_20100921_ubicumque-et-semper.html, citováno dne 19. 1. 2018.

31 Papežská rada pro sdělovací prostředky (Pontificium consilium de communicationibus socialibus) byla kuriálním úřadem, který se na základě kuriální reformy papeže Františka z roku 2015 stal součástí nového Sekretariátu pro komunikaci - viz @ FRANCISCUS, Apostolic Letter Issued Motu Proprio by the Supreme Pontiff Francis for the Establishment of the Secretariat for Communication (online), aktualizace dne 27. 6. 2015, dostupné na http://w2.vatican.va/content/francesco/en/motu_proprio/documents/papa-francescomotu-proprio_20150627_segreteria-comunicazione.html, citováno dne 12.12. 2017.

32 Viz @ Alton J. PELOWSKI, Evangelization and the 'Digital Continent' (on-line), aktualizace dne 12. 9. 2014, dostupné na http://www. pccs.va/index.php/en/news2/attualita/item/2549-evangelization-and-the-digital-continent, citováno dne 19. 1. 2018.

33 ○ Dominikduka.cz, Arcibiskup Celli navštívil Dominika Duku (on-line), aktualizace dne 22. 4. 2013, dostupné na http://www. dominikduka.cz/ze-zivota-dominika-duky/arcibiskup-celli-navstivil-dominika-duku/, citováno dne 18. 1. 2018. 
a cituje z projevu arcibiskupa Celliho: „Musíme jít tam, kde jsou lidé. Dnešní společnosti ovládá internetová kultura. Např́klad Facebook pro nás představuje ohromný kontinent s více než jednou miliardou obyvatel (...) “ ${ }^{34}$ Dále zpráva cituje z přednášky kardinála Celliho na téma využití moderních médií: „Ani ve Vatikánu není přítomnost církve na sociálních sítích ideální, a právě o to usilovněji se jí musíme zabývat a pracovat s katechety, kněžími a biskupy, aby byli na sociálních sítích vidět. “35

Podobně se již v roce 2002 vyjádřil kardinál John Patrick Foley, někdejší př̀edseda Papežské rady pro sdělovací prostředky, ${ }^{36}$ který v dokumentu „Církev a internet“ označil internet nejen za důležitý prostředek k předávání zpráv a informací, ale i k evangelizaci, „re-evangelizaci“, tzv. nové evangelizaci a k některým formám pastorace a katecheze - kardinál tu spojuje využití internetu s konceptem nové evangelizace. ${ }^{37}$

Rozvoj využití internetu Svatým stolcem je spojen s pontifikáty Jana Pavla II. a Benedikta XVI. a dále pokračuje i za pontifikátu papeže Františka. Jan Pavel II. vydal v roce 2002 u př́ležitosti 36. světového dne sdělovacích prostředků poselství „Internet: nové fórum pro hlásání evangelia“.38 Podle Jana Pavla II. stála církev mnohokrát na kulturních rozhraních, která vyžadovala nové formy evangelizace, a probíhající komunikační a informační revoluce je právě takovým prahem. ${ }^{39}$ Jan Pavel II. konstatuje, že internet představuje skvělý prostředek k evangelizaci. ${ }^{40}$

Na Jana Pavla II. navazuje papež Benedikt XVI., když v „Poselství ke 44. světovému dni sdělovacích prostředkü“41 $\mathrm{z}$ roku 2010 hovoří o využívání internetu jako prostředku pastorace a evangelizace a dokonce přirovnává internet k „digitálnímu kontinentu“, který je nutné evangelizovat - tento úkol přísluší podle papeže Benedikta zejména mládeži. ${ }^{42} \mathrm{Na}$ začátku prosince 2012 byla založena oficiální stránka papeže na sociální síti Twitter a 12. prosince téhož roku zde papež Benedikt XVI. zveřejnil svou první krátkou zprávu, tzv. tweet. ${ }^{43}$ Tato twitterová stránka slouží i současnému papeži Františkovi.

Papežovu oficiální profilovou stránku na Twitteru, vedenou v anglickém jazyce, sledovalo k 19. lednu 2018 přes 16 milionů uživatelů. ${ }^{44}$ Stránka má dalších osm jazykových verzí, mimo jiné v latině, francouzštině, arabštině či polštině. Ke konci roku 2017 měly papežovy profilové stránky na Twitteru ve všech devíti jazykových verzích více než 60 milionů sledujících. ${ }^{45}$

Oficiální internetová komunikace církve, tedy i oficiální komunikace pomocí internetových sociálních sítí, je v současnosti řízena Sekretariátem pro komunikaci. Sekretariát je kuriálním úřadem, tzv. dikasteriem, který vznikl v rámci kuriální reformy na základě apoštolského listu motu

34 Tamtéž.

35 Tamtéž.

36 Viz pozn. 20. K Papežské radě pro sdělovací prostředky viz pozn. 31.

37 (C) FOLEY, Dokument...

38 (C) IOANNES PAULUS PP. II, Message of the Holy Father John Paul II for the 36th world communications day 'Internet: A New Forum for Proclaiming the Gospel' (on-line), aktualizace dne 12. 5. 2002, dostupné na https://w2.vatican.va/content/john-paul-ii/en/messages/ communications/documents/hf_jp-ii_mes_20020122_world-communications-day.html, citováno dne 19.1.2018.

39 Tamtéž.

40 Tamtéž.

41 (c) BENEDICTUS PP. XVI, Poselství ke 44. světovému dni sdělovacích prostředků (on-line), aktualizace dne 23. 1. 2010, dostupné na https://www.cirkev.cz/archiv/100123-poselstvi-ke-44-svetovemu-dni-sdelovacich-prostredku, citováno dne 19. 1. 2018.

42 Tamtéž

43 (c) Claire DÍAZ-ORTIZ, The Pope's first Tweets (on-line), aktualizace dne 12. 12. 2012, dostupné na https://blog.twitter.com/official/ en_us/a/2012/the-pope-s-first-tweets.html, citováno dne 12. 12. 2017; @ Devin WATKINS, Pope's Twitter account marks 5 years: 'Useful for evangelization' (on-line), aktualizace dne 11. 12. 2017, dostupné na http://www.vaticannews.va/en/vatican-city/news/2017-12/popes-twitter-account-marks-5-years.html, citováno dne 12. 12. 2017.

44 (C) Twitter, @pontifex (on-line), dostupné na https://twitter.com/Pontifex, citováno dne 19. 1. 2018.

45 (c) WATKINS, Pope's... 
proprio papeže Františka vydaného 27. června 2015. ${ }^{46}$ Papež František konstatuje, že v současném věku digitálních médií je třeba nově zorganizovat komunikační a informační platformy Apoštolského stolce. ${ }^{47} \mathrm{~V}$ gesci nově vzniklého úřadu mají proto nadále být všechna oficiální média Svatého stolce a článek 3. apoštolského listu přímo přiděluje do pravomoci nového úřadu správu papežova twitterového účtu „@pontifex“ a také vatikánského webu www.vatican.va.48

Kromě „papežského“ twitterového účtu slouží Svatému stolci k oficiální komunikaci na sociálních sítích i stránka Vatican News. Jde o informační systém Vatikánu, který vznikl právě v souvislosti s papežovou reformou organizace komunikačních platforem Svatého stolce v roce $2015^{49}$ a který šiŕí informace i prostřednictvím vlastních stránek na online sociálních sítích. Vedle webové stránky v různých jazykových verzích provozuje Vatican News stránky také na Facebooku a na Twitteru. Facebooková stránka je vedena v angličtině a k 19. lednu 2018 ji sledovalo přes 3 miliony uživatelů Facebooku. ${ }^{50}$ Právě zde se často objevují „reposty“ tweetů z oficiální papežovy twitterové stránky. Twitterová stránka Vatican News, rovněž v angličtině, měla ke stejnému dni na 246 tisíc sledujících. ${ }^{51}$

V českém církevním prostředí lze u nejvyšších představitelů církve najít jak vstřícné postoje k využívání internetu a online sociálních sítí, tak vyjádření zdrženlivější. Již v roce 2009 se k online sociálním sítím vyjádřil na svém webu kardinál Miloslav Vlk, který vyzdvihuje důležitost využívání moderních komunikačních prostředků církví, zmiňuje využití Youtube a Facebooku Vatikánem a využití internetu vidí zejména v souvislosti s evangelizací. ${ }^{52}$

Nástupce kardinála Vlka v úřadu pražského arcibiskupa, kardinál Dominik Duka, se k novým komunikačním technologiím vyjadřuje s jistou zdrženlivostí, přestože je jeho prrítomnost na sociálních sítích velmi výrazná. V rozhovoru z roku 2011, uveřejněném na jeho oficiální webové stránce, hovoří kardinál Duka na téma nové evangelizace a zdůrazňuje, že pouhé využívání nových technologií k šíření „propagandy a reklamy“53 ideu tohoto konceptu nenaplňuje. Přes poněkud skeptický postoj je však kardinál Duka používání sociálních sítí nakloněn - svědčí o tom mimo jiné i kardinálův vlastní blogový příspěvek „Facebookový dialog ${ }^{\text {“54 }}$ z roku 2015, kde kardinál Duka představuje svou facebookovou stránku jako prostor k diskuzi o náboženství. Podstatným cílem facebookové diskuze má být podle Duky: „(...) většina obyvatel, která se k náboženství nevyslovuje, přestože k němu má evidentní vztah (...). Diskuze budu záměrně umístovat na v současnosti oblíbenou sociální sít Facebook, nebot ta je v dnešní době církvemi málo probádaným ,kontinentem “" ${ }^{55}$ konstatuje kardinál. O facebookové stránce kardinála Duky jako o platformě k vedení dialogu o víře informuje v roce 2015 i web pražského arcibiskupství. ${ }^{56}$ Kardinála Duku vede $\mathrm{k}$ aktivitě na této sociální síti snaha zahájit pomocí moderních technologií dialog s „,mlčící

\footnotetext{
(c) FRANCISCUS, Apostolic...

Tamtéž.

8 Tamtéž.

49 (c) Vatican News, About Us (on-line), dostupné na http://www.vaticannews.va/en/about-us.html, citováno dne 12. 12. 2017.

0 @ Facebook, @vaticannews (on-line), dostupné na https://www.facebook.com/vaticannews/, citováno dne 19. 1. 2018.

51 @ Twitter, @VaticanNews (on-line), dostupné na https://twitter.com/vaticannews, citováno dne 19. 1. 2018. Kromě Facebooku a Twitteru má Vatican News stránky i na Youtube a na Instagramu.

52 C Miloslav VLK, Moderní komunikační technologie a největší ,komunikátor (on-line), aktualizace dne 25. 5. 2009, dostupné na http:// www.kardinal.cz/index.php?cmd=article\&articleID=348, citováno dne 12. 12. 2017.

53 C D Dominik DUKA - Jan UHLÍř, Současnému člověku nemůžeme nabízet recepty (on-line), aktualizace dne 19. 5. 2011, dostupné z http://www.dominikduka.cz/rozhovory-menu/soucasnemu-cloveku-nemuzeme-nabizet-recepty/, citováno dne 18. 1. 2018.

54 () Dominik DUKA, Facebookový dialog (on-line), aktualizace dne 6. 2. 2015, dostupné na http://blog.aktualne.cz/blogy/dominik-duka. php?itemid=24656, citováno dne 18. 1.2018.

55 Tamtéž.

56 @ Josef NERUŠIL, Facebookový dialog s kardinálem Dukou (on-line), aktualizace dne 6. 2. 2015, dostupné na http://www.apha.cz/ facebookovy-dialog-s-kardinalem-dukou, citováno dne 19. 1.2018.
} 
polovinou' národa" ${ }^{57}$ tedy s těmi, kteří se podle sčítání lidu z roku 2011 nevyjádřili k otázce náboženské př́slušnosti. ${ }^{58}$

Kardinál Duka ve svém blogovém příspěvku využívá přirovnání internetu ke kontinentu, které použil papež Benedikt XVI ${ }^{59}$ Přestože o tom příspěvek kardinála Duky přímo nehovoří, vzhledem $\mathrm{k}$ tomu, jak formuluje cíle facebookové diskuze o víře, jeho vyjádření lze v českém prostředí vnímat v souvislosti s praktickým využíváním online sociálních sítí církví a jejími představiteli jako prostředku nové evangelizace.

Zajímavým způsobem shrnuje tematiku využívání sociálních sítí církví Katolický týdeník, oficiální list České a Moravské církevní provincie. List reflektuje využívání Facebooku církví v článku „Bez Facebooku se církev už neobejde“, uveřejněném v únoru 2014 a dostupném i na webové stránce týdeníku. ${ }^{60}$ Již z titulku je patrné, že autor považuje prezentaci církve prostřednictvím internetových sociálních sítí za nezbytnou. Autor zmiňuje papežův účet na Twitteru a existenci facebookové prezentace Vatikánu. „V posledních letech se stal Facebook nepostradatelným pomocníkem i české církve. Využívají ho věřící, církevní instituce i kněží. Výjimkou není ani český primas kardinál Dominik Duka" ${ }^{61}$ uvádí autor a podrobněji se věnuje právě kardinálově facebookové stránce. Autor cituje vyjádření Josefa Nerušila, ${ }^{62}$ kterého uvádí jako správce kardinálova facebookového profilu: podle Nerušila slouží kardinálův facebookový profil jako prostředek sdílení informací se zástupci dalších médií, za důležité však považuje i sdílení informací s celou komunitou uživatelů Facebooku. ${ }^{63}$ Sdílení informací ze života církve a také postojů církve k událostem ve veřejném životě, které se církve blíže dotýkají, uvádí autor také v souvislosti s facebookovou stránkou České biskupské konference. ${ }^{64}$ Kromě sdílení informací o životě uvnitř církve a o postojích církve a jejích představitelů k dění ve veřejné sféře však autor uvádí ještě další významnou funkci sociálních sítí. Tou je jejich využití jako nástroje evangelizace. K tomu autor cituje vyjádření Josefa Ptáčka, kterého představuje jako metodika informačních technologií Arcibiskupství pražského. ${ }^{65}$ Josef Ptáček uvádí, že Facebook se může stát prostorem pro evangelizaci ve formě osobního svědectví o žité víre a jejím významu. ${ }^{66}$

Vyjdeme-li z citovaných vyjádření představitelů katolické církve k prezentaci církve na sociálních sítích, lze konstatovat, že tento způsob prezentace má v emické rovině dvě základní funkce, ${ }^{67}$ které

57 Tamtéž.

58 Tamtéž

59 (C) BENEDICTUS PP. XVI, Poselství..

60 (C) Jiří PRINZ, Bez Facebooku se církev už neobejde (on-line), aktualizace dne 5. 2. 2014, dostupné na http://www.katyd.cz/clanky/bezfacebooku-se-cirkev-uz-neobejde.html, citováno dne 19. 1. 2018.

61 Tamtéž

62 Josef Nerušil je podle webu Arcibiskupství pražského zaměstnancem arcibiskupského Odboru vnějších vztahů - tiskového střediska, odpovědným za elektronická média - viz @ C Arcibiskupství pražské, Kontakty (on-line), dostupné na http://www.apha.cz/kontakty-nazamestnance, citováno dne 18. 1. 2018. Existenci pozic specializovaných na elektronická média, správu sociálních sítí atp. v organizační struktuře církevních institucí je možné z religionistického hlediska vykládat v souvislosti s konceptem organizační úrovně sekularizace - viz dále v této stati.

63 (C) PRINZ, Bez Facebooku...

64 Tamtéž. Facebooková stránka Tiskového střediska České biskupské konference byla v roce 2016 přejmenována na „Církev.cz“, provázanou s tehdy nově vzniklým stejnojmenným webem - viz (C) Biskupství brněnské, Katolická církev nabízí informace na novém webu Církev. cz (on-line), aktualizace dne 18. 3. 2016, dostupné na https://www.biskupstvi.cz/2016-03-18-katolicka-cirkev-nabizi-informace-nanovem-webu, citováno dne 18. 1. 2018.

65 (c) PRINZ, Bez Facebooku... Databáze osob na webu Arcibiskupství pražského rovněž uvádí Josefa Ptáčka jako metodika informačních technologií - viz (C) Arcibiskupství pražské, Katalog (on-line), dostupné na https://katalog.apha.cz/web/osoby/1440, citováno dne 18. 1. 2018.

66 (c) PRINZ, Bez Facebooku...

67 Zabývám se primárně otázkou, jaké funkce mohou internet a online sociální sítě plnit pro církev - obecnou otázku funkcí náboženství ve společnosti ponechávám záměrně stranou, nebot podobný rozbor v souvislosti se zkoumanou problematikou by vyžadoval samostatnou studii. K funkcím náboženství ve společnosti ze sociálně vědního hlediska viz např. Dušan LUŽNÝ, Náboženství a moderní společnost, Brno: Masarykova univerzita, 1999. K tomuto tématu z obecného teoretického hlediska s uvedením konkrétních empirických příkladů 
však lze vidět ve vzájemném vztahu. První je informační, která spočívá v informování veřejnosti o různých aktivitách církve a $\mathrm{v}$ prezentování postojů církve $\mathrm{k}$ aktuálním událostem a problémům. Druhou lze označit jako evangelizační a pastorační, kdy nové technologie a nová média slouží jako prostředek $\mathrm{k}$ prezentaci a propagaci křestanského (katolického) světonázoru. Je zřejmé, že obě tyto funkce od sebe není možné jednoznačně oddělit, když informace ze života církve jsou $\mathrm{v}$ emické rovině zároveň chápány jako svědectví o životě ve víre. ${ }^{68}$

V českém církevním prostředí je používání internetu a sociálních sítí rovněž spojováno s novou evangelizací, resp. re-evangelizací, o tomto konceptu hovoří v souvislosti s využíváním nových technologií i kardinál Dominik Duka, přestože se k využití internetu jako evangelizačního nástroje staví s jistou opatrností. ${ }^{69} \mathrm{~V}$ každém př́padě jsou internet a online sociální sítě v emické rovině vnímány zejména jako prostředek i prostor pro šíření evangelia, ${ }^{70}$ byt lze nalézt i výzvy k opatrnosti při využívání internetu a online sociálních sítí. ${ }^{71}$

Důležitou souvislostí využívání internetu a online sociálních sítí církví, která vyplývá přímo z citovaných církevních dokumentů, je zacílení na mládež. V souvislosti s novou evangelizací o tom hovoří oficiální papežské dokumenty ${ }^{72}$ a využití online sociálních sítí $\mathrm{k}$ evangelizaci a pastoraci mezi mládeží je i předmětem dokumentů, které lze nalézt v českém církevním prostř̌edí. ${ }^{73}$

Není jistě překvapivým zjištěním, že vyjádření postojů církevních představitelů k prezentaci na online sociálních sítích v českém prostř̌edí korespondují s př́stupem, který k online sociálním sítím a internetu ve svých dokumentech zaujímá Svatý stolec a jeho instituce. Jaký je tedy současný stav prrítomnosti české katolické církve na sociálních sítích?

\section{Prezentace církevních nejvyšších institucí a jejich představitelů na sociálních sítích}

Stránky české katolické církve na sociální síti Facebook dělím pro přehlednost do tří skupin. První z nich tvoří stránky arcibiskupství a biskupství, druhou stránky nejvyšších církevních představitelů na této úrovni, tedy arcibiskupů a biskupů. Do třetí skupiny řadím ostatní instituce katolické církve na úrovni arcibiskupství a biskupství a ČBK a také stránky Katolického týdeníku jako oficiální mediální platformy České a Moravské církevní provincie, podle výše popsaných kritérií. Dominantní postavení Facebooku mezi internetovými sociálními sítěmi v českém prostředí potvrzuje srovnání stránek jednotlivých institucí církve a představitelů katolické církevní hierarchie na sítích Facebook a Twitter $\mathrm{z}$ hlediska počtu uživatelů, kteří tyto stránky sledují. Srovnání facebookových stránek církevních institucí a představitelů $s$ účty na Twitteru provádím $\mathrm{z}$ toho důvodu, že právě Twitter je platformou, která primárně slouží prezentaci Svatého stolce - právě zde existuje oficiální profilová stránka nejvyšší církevní instituce.

Na sociální síti Facebook lze na dopad stránek na uživatele sítě usuzovat ze dvou údajů, které jsou na jednotlivých stránkách obvykle dostupné - jde o počet uživatelů, kteří stránku označili

viz Daniel V. A. OLSON - Detlef POLLACK, ed., The Role of Religion in Modern Societies, New York: Routledge, 2008.

68 Srov. tamtéž.

69 Viz @ DUKA - UHLÍř, Současnému...

70 Srov. napřr. @ Arcibiskupství pražské, Pastorační plán Arcidiecéze pražské 2014-2019 (on-line), s. 18, dostupné na http://www.apha.cz/ file/22192/pastoracni-plan-arcidieceze-prazske-2014-2019.pdf, citováno dne 19. 1. 2018.

71 Viz např. Jan BALÍK, ed., Na cestě k člověku - témata pro společenství mladých lidí, místo vydání neuvedeno: Sekretariát Sekce pro mládež ČBK a AKSM, 2014, s. 67-73; srov. Direktáŕ pro službu a život kněží, Praha: Sekretariát České biskupské konference, 2016, s. 87.

72 Viz napr. () Benedictus PP. XVI, Poselství...

73 BALÍK, Na cestě..., s. 67-73. 
volbou „Tohle se mi líbi“, a dále o počet uživatelů, kteří danou stránku označili volbou „Sledovat“74 U osobních stránek na síti Facebook se lze stát „prrítelem“ osoby, které stránka patří - Facebook však počet přátel určitým způsobem omezuje, takže uživatelé nad tento limit mohou takovou stránku označit jen volbou „Sledovat“. Twitter ukazuje údaj o počtu uživatelů, kteří danou stránku sledují. Přehled stránek sloužících jako oficiální platformy církve na online sociálních sítích v českém prostředí a počty sledujících ukazují, že hlavní komunikační platformou církevních institucí a představitelů je sociální sít Facebook.

Stránky nejvyšších institucí církevní správy a jejich představitelů v obou církevních provinciích ukazují následující přehledové tabulky, které zároveň zahrnují i počty sledujících, označení volbou „Tohle se mi líbí“ a další základní údaje těchto stránek v lednu $2018^{75}$ u internetových sociálních sítí Facebook a Twitter.

\section{Přehled stránek na sociálních sítích}

\begin{tabular}{|c|c|c|c|}
\hline Název stránky / uživatelské jméno & Sledují & $\begin{array}{l}\text { „Tohle se mi } \\
\text { líbi“ }\end{array}$ & Kategorie stránky dle Facebooku \\
\hline $\begin{array}{l}\text { Arcibiskupství pražské / } \\
\text { @arcibiskupství }^{76}\end{array}$ & 4646 & 4701 & Náboženská organizace \\
\hline Diecéze plzeňská / @bip.cz ${ }^{77}$ & 997 & 982 & Náboženská organizace \\
\hline $\begin{array}{l}\text { Diecéze ostravsko-opavská / } \\
\text { @doo.cz }\end{array}$ & 815 & 795 & Náboženská organizace \\
\hline $\begin{array}{l}\text { Královéhradecká diecéze / } \\
\text { @diecezekralovehradecka }{ }^{79}\end{array}$ & 788 & 789 & Náboženská organizace \\
\hline Biskupství brněnské / @biskupstvi ${ }^{80}$ & 622 & 609 & Náboženská organizace \\
\hline Biskupství litoměřické / @dltm.cz ${ }^{81}$ & 587 & 589 & Náboženská organizace \\
\hline $\begin{array}{l}\text { Biskupství českobudějovické - ofici- } \\
\text { ální stránka }{ }^{82}\end{array}$ & 538 & 531 & Náboženská organizace \\
\hline
\end{tabular}

74 Volbou „Tohle se mi líbí na síti Facebook vyjadřuje uživatel stránce podporu a zároveň se uživateli zobrazují aktualizace na takto označené stránce. Volba „Sledovat“ znamená, že se uživateli zobrazují jen aktualizace takto označené stránky, aniž by stránce zároveň vyjádř̀il i podporu.

75 Není-li uvedeno jinak, jsou údaje o počtu sledujících či označení volbou „Tohle se mi líbí v tabulkách i v celém textu u stránek na sociálních sítích uvedeny $\mathrm{k}$ datu 19. ledna 2018. Všechny stránky uvedené v tabulkách splňovaly $\mathrm{k}$ tomuto datu kritéria $\mathrm{k}$ zařazení do přehledu, i když v některých případech jsou počty sledujících a označení volbou „Tohle se mi líbí“ citovány k pozdějšímu datu.

76 ๑) Facebook, Arcibiskupství pražské (on-line), dostupné na https://www.facebook.com/arcibiskupstvi/, citováno dne 19.1.2018.

77 @ Facebook, Diecéze plzeňská (on-line), dostupné na https://www.facebook.com/bip.cz/, citováno dne 19. 1. 2018.

78 (c) Facebook, Diecéze ostravsko-opavská (on-line), dostupné na https://www.facebook.com/doo.cz/, citováno dne 19. 1. 2018.

79 (c) Facebook, Královéhradecká diecéze (on-line), dostupné na https://www.facebook.com/diecezekralovehradecka/, citováno dne 19. 1. 2018.

80 ๑) Facebook, Biskupství brněnské (on-line), dostupné na https://www.facebook.com/biskupstvi/, citováno dne 19. 1. 2018.

81 C Facebook, Biskupství litoměřické (on-line), dostupné na https://www.facebook.com/dltm.cz/, citováno dne 19. 1. 2018.

82 (C) Facebook, Biskupství českobudějovické - oficiální stránka (on-line), dostupné na https://www.facebook.com/Biskupstvíčeskobudějovické-oficiální-stránka-342657039165153, citováno dne 19. 1. 2018. 


\begin{tabular}{|c|c|c|c|c|}
\hline \multicolumn{5}{|c|}{ Facebook - arcibiskupové a biskupové } \\
\hline $\begin{array}{l}\text { Název stránky / uživatelské } \\
\text { jméno }\end{array}$ & Sledují & $\begin{array}{r}\text { „Tohle se mi } \\
\text { líbíi“ }\end{array}$ & $\begin{array}{r}\text { Přátelé (osobní } \\
\text { stránky) }\end{array}$ & $\begin{array}{l}\text { Kategorie stránky dle } \\
\text { Facebooku }\end{array}$ \\
\hline $\begin{array}{l}\text { Dominik Duka (Arcibis- } \\
\text { kup pražský) }\end{array}$ & 12386 & - & 4483 & Osobní profilová stránka \\
\hline $\begin{array}{l}\text { Mons. Václav Malý / } \\
\text { @biskup.maly }\end{array}$ & 4968 & 4760 & & $\begin{array}{l}\text { Stránka veřejně známé } \\
\text { osobnosti }\end{array}$ \\
\hline $\begin{array}{l}\text { Pavel Konzbul / } \\
\text { @biskupPavel }\end{array}$ & 4113 & 3996 & - & Veřejně známá osobnost \\
\hline
\end{tabular}

\begin{tabular}{|c|c|c|c|c|}
\hline \multicolumn{5}{|c|}{ Facebook - ostatní stránky arcibiskupských a biskupských institucí } \\
\hline Název stránky / uživatelské jméno & Sledují & $\begin{array}{l}\text { "Tohle se } \\
\text { mi líbí“ }\end{array}$ & $\begin{array}{l}\text { Přátelé } \\
\text { (osobní } \\
\text { stránky) }\end{array}$ & $\begin{array}{l}\text { Kategorie stránky dle Face- } \\
\text { booku (poznámka - provozo- } \\
\text { vatel) }\end{array}$ \\
\hline Víra.cz / @Vira.cz ${ }^{86}$ & 9230 & 9342 & - & $\begin{array}{l}\text { Vzdělávací web (Pastorační } \\
\text { středisko Arcibiskupství praž- } \\
\text { ského) }\end{array}$ \\
\hline $\begin{array}{l}\text { Manželství krok za krokem / } \\
\text { @manzelstvikrokzakrokem }{ }^{87}\end{array}$ & 4337 & 4322 & - & $\begin{array}{l}\text { Organizace (Pastorační středis- } \\
\text { ko - Centrum pro rodinu) }\end{array}$ \\
\hline Církev.cz / @cirkev.cz ${ }^{88}$ & 3820 & 3812 & - & $\begin{array}{l}\text { Náboženská organizace (Tisko- } \\
\text { vé středisko ČBK) }\end{array}$ \\
\hline Katolický týdeník / @KaTyd.cz ${ }^{89}$ & 3418 & 3454 & - & Vydavatel \\
\hline Liturgie.cz / @Liturgie.cz ${ }^{90}$ & 2121 & 2134 & - & $\begin{array}{l}\text { Web pro společnost a kulturu } \\
\text { (Pastorační středisko Arcibis- } \\
\text { kupství pražského) }\end{array}$ \\
\hline Děti.víra.cz / @deti.vira.cz ${ }^{91}$ & 1883 & 1885 & - & $\begin{array}{l}\text { Web pro děti a náctileté (Pasto- } \\
\text { rační středisko Arcibiskupství } \\
\text { pražského) }\end{array}$ \\
\hline $\begin{array}{l}\text { ADCM Olomouc / } \\
\text { @ADCMOlomouc }{ }^{92}\end{array}$ & 1381 & 1390 & - & $\begin{array}{l}\text { Náboženské centrum (Arci- } \\
\text { diecézní centrum mládeže Olo- } \\
\text { mouc, Arcidiecéze olomoucká) }\end{array}$ \\
\hline Modlitba.cz / @cz.modlitba ${ }^{93}$ & 1062 & 1062 & - & $\begin{array}{l}\text { Vzdělání (Pastorační středisko } \\
\text { Arcibiskupství pražského) }\end{array}$ \\
\hline
\end{tabular}

83 @) Facebook, Dominik Duka (Arcibiskup pražský) (on-line), dostupné na https://www.facebook.com/dominik.duka.3, citováno dne 19. 1.2018.

84 ○ Facebook, Mons. Václav Malý (on-line), dostupné na https://www.facebook.com/biskup.maly/, citováno dne 19. 1. 2018.

85 C F Facebook, Pavel Konzbul (on-line), dostupné na https://www.facebook.com/pg/biskupPavel, citováno dne 19. 1. 2018.

86 (c) Facebook, Víra.cz (on-line), dostupné na https://www.facebook.com/vira.cz/, citováno dne 19.1. 2018.

87 C Facebook, Manželství krok za krokem (on-line), dostupné na https://www.facebook.com/manzelstvikrokzakrokem/, citováno dne 19. 1.2018

88 @ Facebook, Církev.cz (on-line), dostupné na https://www.facebook.com/Cirkev.cz/, citováno dne 19. 1. 2018.

89 (c) Facebook, Katolický týdeník (on-line), dostupné na https://www.facebook.com/KaTyd.cz/, citováno dne 19. 1. 2018.

90 ๑) Facebook, Liturgie.cz (on-line), dostupné na https://www.facebook.com/Liturgie.cz/, citováno dne 19. 1. 2018.

91 ○ Facebook, Děti.víra.cz (online), dostupné na https://www.facebook.com/deti.vira.cz/, citováno dne 19. 1. 2018.

92 (c) Facebook, ADCM Olomouc (on-line), dostupné na https://www.facebook.com/pg/ADCMOlomouc/, citováno dne 19. 1. 2018.

93 C Facebook, Modlitba.cz (on-line), dostupné na https://www.facebook.com/cz.modlitba/, citováno dne 19. 1. 2018. 


\begin{tabular}{|c|c|c|c|c|}
\hline ADCM Praha / @Praha.ADCM ${ }^{94}$ & 816 & 828 & - & $\begin{array}{l}\text { Náboženská organizace (Arci- } \\
\text { diecézní centrum pro mládež } \\
\text { Praha) }\end{array}$ \\
\hline Pastorace.cz / @spiritualita0195 & 770 & 745 & - & $\begin{array}{l}\text { Vzdělání (Pastorační středisko } \\
\text { Arcibiskupství pražského) }\end{array}$ \\
\hline DCM Brno ${ }^{96}$ & 751 & 757 & - & Náboženská organizace \\
\hline $\begin{array}{l}\text { Diecézní centrum pro mládež } \\
\text { Hradec Králové }^{77}\end{array}$ & 570 & 565 & - & $\begin{array}{l}\text { Náboženská organizace - Nábo- } \\
\text { ženské centrum }\end{array}$ \\
\hline $\begin{array}{l}\text { Diecézní centrum mládeže České } \\
\text { Budějovice / @dcmcb }{ }^{98}\end{array}$ & 514 & 525 & - & Náboženská organizace \\
\hline DCM Plzeň / @DCMPlzen ${ }^{99}$ & 297 & 291 & - & Komunita \\
\hline $\begin{array}{l}\text { Diecézní Centrum pro Mládež } \\
\text { Litoměřice / @ dcmlit }{ }^{100}\end{array}$ & 273 & 277 & - & Komunitní centrum - komunita \\
\hline $\begin{array}{l}\text { Katechetické a pedagogické centrum } \\
\text { Ostrava / @ostravakpc }{ }^{101}\end{array}$ & 217 & 221 & - & Náboženská organizace \\
\hline $\begin{array}{l}\text { Katechetické středisko AP / } \\
\text { @Katecheticke.stredisko.AP }{ }^{102}\end{array}$ & 213 & 223 & - & $\begin{array}{l}\text { Náboženské centrum - Nábo- } \\
\text { ženská organizace (Arcibiskup- } \\
\text { ství pražské) }\end{array}$ \\
\hline
\end{tabular}

\section{Twitter}

\section{Název stránky / uživatelské Počet sledují- Poznámka} jméno Arcibiskupství / @apha_cz ${ }^{103}$

Dominik Duka / @dominikduka ${ }^{104}$

Tomáš Holub / @TomasHolubPB ${ }^{105}$

Víra.cz / @wwwViraCz ${ }^{106}$

\section{Stránka Arcibiskupství pražského}

\section{Stránka arcibiskupa Dominika Duky}

1983 Stránka biskupa Tomáše Holuba

702 Stránka webu Víra.cz (Pastorační středisko Arcibiskupství pražského)

Na základě přehledu v tabulkách lze odpovědět na otázky, jaký je současný stav prezentace nejvyšších institucí české církevní správy a jejich představitelů na sociálních sítích a kolik uživatelů

94 ㄷ) Facebook, ADCM Praha (on-line), dostupné na https://www.facebook.com/Praha.ADCM/, citováno dne 19. 1. 2018.

95 (c) Facebook, Pastorace.cz (on-line), dostupné na https://www.facebook.com/spiritualita01/, citováno dne 19. 1. 2018.

96 (c) Facebook, DCM Brno (on-line), dostupné na https://www.facebook.com/DCM-Brno-335046847299/, citováno dne 18. 6. 2018.

97 ○ Facebook, Diecézní centrum pro mládež Hradec Králové (on-line), dostupné na https://www.facebook.com/Diecézní-centrum-promládež-Hradec-Králové-1479375009009788/, citováno dne 19. 1. 2018.

98 C F Facebook, Diecézní centrum mládeže České Budějovice (on-line), dostupné na https://www.facebook.com/dcmcb/, citováno dne 18. 6. 2018.

99 C Facebook, DCM Plzeň (on-line), dostupné na https://www.facebook.com/pg/DCMPlzen/about/?ref=page_internal, citováno dne 18. 6. 2018.

100 (c) Facebook, Diecézní Centrum pro Mládež Litoměřice (on-line), dostupné na https://www.facebook.com/pg/dcmlit/, citováno dne 19. 1. 2018.

101 C) Facebook, Katechetické a pedagogické centrum Ostrava (on-line), dostupné na https://www.facebook.com/pg/ostravakpc/, citováno dne 19. 1. 2018.

102 ○) Facebook, Katechetické středisko AP (on-line), dostupné na https://www.facebook.com/pg/Katecheticke.stredisko.AP/, citováno dne 19. 1. 2018.

103 @ Twitter, Arcibiskupství (on-line), dostupné na https://twitter.com/apha_cz, citováno dne 19. 1. 2018.

104 ○ Twitter, Dominik Duka (on-line), dostupné na https://twitter.com/dominikduka, citováno dne 19. 1. 2018.

105 @) Twitter, Tomáš Holub (on-line), dostupné na https://twitter.com/TomasHolubPB, citováno dne 19. 1. 2018.

106 (c) Twitter, Víra.cz, dostupné na https://twitter.com/wwwViraCz, citováno dne 19. 1. 2018. 
sociálních sítí jejich stránky sleduje.

Z nejvyšších institucí české katolické církve na úrovni arcibiskupství a biskupství má svou oficiální stránku na Facebooku pražská arcidiecéze a všechna biskupství, pouze olomoucká arcidiecéze se na internetové sociální síti doposud oficiálně neprezentuje. ${ }^{107}$ Nejvíce sledujících má facebooková stránka pražské arcidiecéze, ${ }^{108}$ která se zároveň prezentuje i prostř̌ednictvím sítě Twitter. ${ }^{109}$

$\mathrm{Z}$ představitelů vysokého kléru české katolické církve na nejvyšších institucionálních úrovních církevní správy mají oficiální stránky na sociálních sítích kardinál Dominik Duka, arcibiskup pražský, Václav Malý, pomocný biskup pražský, Tomáš Holub, biskup plzeňský a Pavel Konzbul, pomocný biskup brněnský. ${ }^{110}$ Arcibiskup Dominik Duka má stránky na sítích Facebook ${ }^{111}$ i Twitter, ${ }^{112}$ Václav Malý a Pavel Konzbul pouze na Facebooku ${ }^{113}$ a Tomáš Holub jen na Twitteru. ${ }^{114}$ Facebooková stránka kardinála Duky je zároveň nejsledovanější prezentací oficiálně spojenou s katolickou církví na českých sociálních sítích. Ostatní biskupové své oficiální stránky na sociálních sítích nemají. ${ }^{115}$

Česká biskupská konference, resp. její tiskové středisko, disponuje stránkou na Facebooku, ${ }^{116}$ která je provázána s webem Církev.cz. Přestože web Církev.cz uvádí i odkaz na vlastní twitterovou stránku, samostatná twitterová stránka tohoto webu ke dni 19. ledna 2018 neexistovala a odkaz vedl na twitterový profil Stanislava Přibyla, generálního sekretáře ČBK, jehož profilová stránka je označena jako osobní. ${ }^{117}$ Katolický týdeník, oficiální periodikum ČBK, disponuje na Facebooku vlastní stránkou. ${ }^{118}$

Zvláštní kapitolou jsou webové projekty Pastoračního střediska Arcibiskupství pražského a jejich profily na sociálních sítích. Sledujeme-li prezentace církve na sociálních sítích, nemají projekty Pastoračního stř̌ediska svým koncepčním pojetím a rozsahem v českém prostředí obdoby. ${ }^{119}$

107 Na Facebooku lze nalézt pouze stránku olomouckého arcibiskupa Jana Graubnera na adrese https://www.facebook.com/graubner.jan/, která je však označena jako neoficiální a kterou ke dni 19. ledna 2018 sledovalo 1504 uživatelů. Volbou „Tohle se mi líbi“ stránku označilo 1497 uživatelů.

108 ๑ Facebook, Arcibiskuptsví pražské...

109 @ Twitter, Arcibiskupství... Z biskupství v obou církevních provinciích se na síti Twitter prezentuje ještě Biskupství litoměřické, které však k 19. lednu 2018 sledovalo pouze 89 uživatelů - viz @ Twitter, Biskupství LTM (on-line), dostupné na https://twitter.com/dltm_cz, citováno dne 19. ledna 2018.

110 Na síti Facebook má na adrese https://www.facebook.com/MiloslavKardinalVlk/ doposud svou stránku i kardinál Miloslav Vlk, zesnulý v březnu 2017, stránka měla ke dni 19. ledna 20183024 sledujících, volbou „Tohle se mi líbí ji označilo 3003 uživatelů. Stránku lze považovat za oficiální, nebot̉ odkaz na ni je umístěn na kardinálově oficiální webové stránce http://www.kardinal.cz/.

111 () Facebook, Dominik Duka...

112 @ C Twitter, Dominik Duka... Kardinál Dominik Duka má rovněž vlastní kanál na Youtube, který sledovalo ke dni 19. ledna 2018 93 uživatelů a ode dne zř́zení kanálu (28. června 2013) má obsah kanálu celkem 15609 zhlédnutí - viz @ Youtube, Dominik kardinál Duka (on-line), dostupné na https://www.youtube.com/channel/UCSRtwE5pdi75bzb9MgkZ-6w, citováno dne 19. ledna 2018; Viz i @ Josef NERUŠIL, Kardinál Duka na Youtubu (on-line), aktualizace dne 1. 12. 2013, dostupné na http://www.apha.cz/kardinal-duka-nayoutubu, citováno dne 19. ledna 2018.

113 @ Facebook, Mons. Václav Malý...; ( Facebook, Pavel Konzbul...

114 ๑ Twitter, Tomáš Holub...

115 Kromě neoficiální stránky arcibiskupa Graubnera (viz pozn. 107) lze najít ještě stránku litoměřického biskupa Jana Baxanta s 476 sledujícími a 481x označením „Tohle se mi líbí, stránka však není označena jako oficiální a poslední příspěvek na stránce je ke 14. březnu 2013. Stránka je tedy dlouhodobě neaktivní - viz @ Facebook, Jan Baxant (on-line), dostupné na https://www.facebook.com/ Jan-Baxant-115968705395/, citováno dne 19. 1. 2018. Biskup František Lobkowitz má na Facebooku jen soukromou osobní stránku - že jde o autentickou osobní stránku, lze usuzovat jen nepřímo, na základě veřejně dostupného seznamu profilů přátel této osobní stránky. Stránka sama není veřejně přístupná - viz @ Facebook, František Lobkowitz (on-line), dostupné na https://www.facebook.com/people/ František-Lobkowicz/100021840347710, citováno dne 19. 1. 2018.

116 @ Facebook, Církev.cz...

117 (c) Twitter, Stanislav Přibyl (on-line), dostupné na https://twitter.com/pribylst, citováno dne 19. 1. 2018.

118 @) Facebook, Katolický týdeník... Katolický týdeník má stránku i na síti Twitter, sleduje ji však pouze 192 uživatelů - viz Twitter, Katolický týdeník (on-line), dostupné na https://twitter.com/katydcz, citováno dne 19. 1. 2018.

119 Pastorační středisko Arcibiskupství pražského provozuje ještě vlastní facebookovou stránku pod názvem „Pastorační stř̌edisko“ na adrese https://www.facebook.com/Pastorační-stř̌edisko-162072743930515. Ke dni 19. 1. 2018 však zde byl poslední příspěvek umístěn k datu 15. 1. 2014 - stránku lze tedy považovat za dlouhodobě neaktivní. 
Z hlediska počtu uživatelů Facebooku, kteří stránky provozované Pastoračním střediskem sledují, je nejpopulárnějši facebooková stránka Víra.cz, ${ }^{120}$ obsahově spojená se stejnojmenným webem. Stránku tohoto webu najdeme i na Twitteru, ${ }^{121}$ kde však má podstatně méně sledujících uživatelů. K dalším stránkám, které se prezentují prostřednictvím Facebooku a jsou provozovány pražským Pastoračním střediskem, patří stránky Liturgie.cz, ${ }^{122}$ Manželství krok za krokem - Manželství. Cz, ${ }^{123}$ Modlitba.cz, ${ }^{124}$ Pastorace.cz ${ }^{125}$ a Děti.víra.cz. ${ }^{126}$ Všechny tyto stránky na Facebooku jsou provázány se stejnojmennými webovými stránkami. Podobné stránky, zaměřené zejména na práci s mládeží, provozují př́slušná střediska i při dalších diecézích, i když ve srovnání se stránkami pražské arcidiecéze mají menší počet uživatelů.

Údaje o počtech sledujících uživatelů ukazují, že sledovanost těchto stránek je spiše nízká. Je však zřejmé, že instituce na nejvyšších úrovních církevní správy usilují o systematickou př́tomnost na sociálních sítích, přestože absence oficiální prezentace olomouckého arcibiskupství na sociálních sítích svědčí o tom, že katolická církev nevyužívá plně potenciál, který sociální sítě nabízejí. Z arcibiskupství a biskupství je z hlediska počtu uživatelů nejsledovanější stránka Arcibiskupství pražského, jehož organizační složky také na Facebooku vyvíjejí mezi uvedenými církevními institucemi nejvýraznější aktivity. Mezi nejvyššími představiteli církve, biskupy a arcibiskupy, je vlastní profil na sociálních sítích méně obvyklou záležitostí. V lednu 2018 má česká katolická církev (včetně apoštolského exarchátu) celkem 22 biskupů, ${ }^{127}$ spolu s arcibiskupy kardinálem Dominikem Dukou a Janem Graubnerem. Stránku kardinála Dominika Duky, vedenou jako otevřený oficiální osobní profil, lze co do počtu sledujících uživatelů považovat za nejvýznamnější oficiální stránku spojenou s nejvyššími institucemi církevní správy v České republice.

Z tematického zaměření stránek je zřejmé, že kromě vlastních stránek biskupství coby institucí jsou na sociálních sítích provozovány zejména stránky, které jsou zaměřeny na oblast evangelizace, pastorace a katecheze, a některé $\mathrm{z}$ nich explicitně cílí na práci s dětmi a mládeží. ${ }^{128}$

\section{Církev a online sociální média pohledem religionistilky}

Z hlediska religionistiky, chápané jako sociálně vědní studium náboženství v sociokulturních souvislostech v diachronní i synchronní perspektivě, ${ }^{129}$ je nezbytné otázku prezentace církve na online sociálních sítích vztahovat ke konkrétním sociokulturním souvislostem. Východiskem je však vždy emická rovina problematiky, tj. v našem př́ípadě způsob, jakým je dané téma vykládáno uvnitř samotné církve. Chceme-li poskytnout etický pohled - tedy pohled z hlediska

120 ๑) Facebook, Víra.cz...

121 (c) Twitter, Víra.cz...

122 ○ Facebook, Liturgie.cz... Stránka webu Liturgie.cz se prezentuje i prostřednictvím Twitteru, sleduje ji však pouze 110 uživatelů - @ Twitter, Liturgie.cz, dostupné na https://twitter.com/liturgie_cz, citováno dne 19. 1. 2018.

123 ๑ Facebook, Manželství krok za krokem... Tuto stránku spolu s webem Manželství.cz provozuje Centrum pro rodinu Pastoračního střediska pražského arcibiskupství - viz @ Ludmila PIVOŇKOVÁ, Centrum pro rodinu (on-line), aktualizace dne 4. 4. 2017, dostupné z http://www.apha.cz/cpr, citováno dne 19. 1. 2018.

124 (c) Facebook, Modlitba.cz...

125 (c) Facebook, Pastorace.cz...

126 (c) Facebook, Děti.víra.cz...

127 @ Cirkev.cz, Biskupové (on-line), dostupné na https://www.cirkev.cz/cs/biskupove, citováno dne 23. 1. 2018. Započítáni jsou rovněž emeritní biskupové a také pomocný biskup pražský Zdenek Wasserbauer, který byl papežem Františkem jmenován 23. ledna 2018 a k lednu 2018 tedy ještě neobdržel biskupské svěcení - viz @ František JEMELKA, Pražská arcidiecéze má nového pomocného biskupa (on-line), aktualizace dne 23. 1. 2018, dostupné na https://www.cirkev.cz/cs/aktuality/180123prazska-arcidieceze-ma-novehopomocneho-biskupa, citováno dne 29. 1. 2018.

128 Analýza vlastního obsahu stránek, např́iklad z pozic mediálních studií, představuje další možný směr badatelské práce.

129 Teoretická východiska religionistiky v tomto směru shrnuje William E. PADEN, Bádání o posvátnu. Náboženství ve spektru interpretací, Brno: Masarykova univerzita, 2002. 
objektivizující vědy - na zkoumanou problematiku, musíme jej nezbytně založit právě na kontextu, $\mathrm{v}$ němž se objevuje $\mathrm{v}$ samotném církevním prostředí.

Problematiku využití internetu církví a s tím související využívání online sociálních sítí uvádí do určitého kontextu př́mo církevní dokumenty, jako je například výše citované prohlášení papeže Jana Pavla II. z roku 2002, ${ }^{130} \mathrm{v}$ němž papež hovoří o kulturních změnách a o změnách v komunikaci, které církev přivádí k novému prahu, jejž je třeba překročit. ${ }^{131}$ Lze říci, že církev využívá internet $\mathrm{v}$ reakci na měnící se sociokulturní situaci. Slovy ekonomického modelu náboženství, ${ }^{132}$ církve a náboženské společnosti jsou vedeny k novým marketingovým strategiím na „náboženském trhu“ ${ }^{133} \mathrm{v}$ globální i lokální perspektivě. $\mathrm{V}$ této souvislosti lze znovu připomenout slova papeže Jana Pavla II. k 36. světovému dni sdělovacích prostředků, kde papež přirovnává internet $\mathrm{k}$ někdejším fórům antického světa a připomíná, že tato fóra jako místa sociální interakce v nejširší perspektivě sloužila jako tržiště a zároveň i místa naplňování náboženských povinností. ${ }^{134}$ Existence stránek církevních představitelů a institucí na online sociálních sítích je tedy př́kladem snahy církve reagovat na sociokulturní změny, doprovázené mimo jiné změnami v komunikačních strategiích, rozšířením internetu a s ním spojených nových médií, například právě internetových sociálních sítí.

Využití internetu k evangelizaci je $\mathrm{v}$ samotném církevním prostředí zároveň uváděno do souvislosti s konceptem nové evangelizace, ${ }^{135}$ chápané jako re-evangelizace tam, kde dochází k odklonu obyvatelstva od již dříve přijaté víry. V religionistické, etické perspektivě lze proto využití internetu a online sociálních sítí církví vykládat v souvislosti se sekularizací v moderní společnosti. Sekularizace je ve starší sociologické literatuře definována jako situace, $v$ níž náboženské myšlení, praktiky a instituce ztrácejí svůj společenský význam. ${ }^{136}$ Tento koncept sekularizace je však dnes považován za značně zjednodušující a v podstatě vycházející z ideologie osvícensko-racionalistické sekularizační teze, která „úpadek“ náboženství v moderních společnostech prostě předpokládá. ${ }^{137}$ Novější sociálně vědní bádání opouští ideologicky zabarvenou dikci „mizení či dokonce „úpadku“ náboženství a pokouší se uchopit problematiku sekularizace jako souhrn procesů na různých úrovních společnosti a kultury, které v souvislosti s funkcionální diferenciací provázejí proměny rolí náboženství v moderních společnostech, resp. některých typech moderních společností. ${ }^{138}$

Teoretik sekularizace Karel Dobbelaere rozlišuje tři základní úrovně, na nichž lze v souvislosti se sekularizací pozorovat různé procesy změn a zároveň používat různé teoretické a konceptualizační nástroje $\mathrm{k}$ jejich popisu a analýze: individuální, organizační a societální. ${ }^{139}$ Tyto úrovně, na nichž lze sekularizační procesy zkoumat, nejsou samozřejmě striktně odděleny, dovolují však

130 ○ IOANNES PAULUS PP. II, Message...

131 Tamtéž.

132 Tuto perspektivu z hlediska př́nosů i slabých stránek shrnuje Dušan LUŽNÝ, Teorie racionální volby v současné sociologii náboženství, Sociológia 2/2015, s. 151-170.

133 S metaforou náboženského „trhu“ v teoretické rovině pracuje Larry WITHAM, Marketplace of the Gods: How Economics Explains Religion, Oxford: Oxford University Press, 2010.

134 C IOANNES PAULUS PP. II, Message...

135 Spojení pojmu nové evangelizace s využitím internetu dokládají vyjádření církevních představitelů, která byla citována výše - viz nap̌r. (c) PELOWSKI, Evangelization... Srov. také ( ) FOLEY, Dokument..

136 Bryan WILSON, Religion in Secular Society: A Sociological Comment, London: C. A. Watts, 1966, s. xiv.

137 Výtečný kritický přehled literatury k tzv. sekularizačnímu paradigmatu v sociálních vědách podává Roman VIDO, Konec velkého vyprávění? Sekularizace v sociologické perspektivě, Brno: CDK, 2011.

138 Kritické přehodnocení modelů sekularizace z tohoto hlediska podává Steve BRUCE, Secularization. In Defence of an Unfashionable Theory, Oxford: Oxford University Press, 2011.

139 Tř́úrovňový model sekularizačních procesů je koncepčním základem publikace Karel DOBBELAERE, Secularization: An Analysis on Three Levels, Brussels: Peter Lang, 2002. 
teoreticky uchopit komplexní problematiku proměn, kterými náboženství v moderních společnostech prochází.

Na individuální úrovni sekularizace klesá ve společnosti míra otevřeně deklarované příslušnosti k určitému náboženskému světonázoru, reprezentovanému určitým církevním společenstvím. Nesmíme se však nechat dovést k zavádějícímu závěru, že náboženství proto ve společnosti mizí. V souvislosti s tím probíhá privatizace a individualizace náboženství, roste význam náboženské „brikoláže“ na individuální úrovni ${ }^{140}$ a náboženství se stává spíše soukromou záležitostí jednotlivců. ${ }^{141} \mathrm{~V}$ sekularizované společnosti, vykazující na individuální úrovni klesající míru deklarované náboženské prŕíslušnosti k etablovaným církvím a náboženským společnostem, musí katolická církev hledat odpovídající formy šíření a udržování náboženského světonázoru. Internet a online sociální sítě jsou k tomu vhodným prostředkem i prostředím, z tohoto důvodu jsou církví označovány jako prostředek i cíl evangelizační a pastorační činnosti. Nová evangelizace se tak stává mimo jiné evangelizací pomocí nových technologických prostředků, ${ }^{142}$ například právě s využitím nových médií. Takto vedená evangelizace může mít samozřejmě dopad či projevy na více úrovních, nejen individuální, ale i societální a organizační.

Pokud jde o míru deklarované individuální náboženské příslušnosti k církvím a náboženským společnostem, lze českou společnost považovat za vysoce sekularizovanou. ${ }^{143}$ Současná česká společnost se zároveň vyznačuje častým užíváním internetu a online sociálních sítí. V českém prostředí je proto využití sociálních médií k udržování a šíření náboženského světonázoru na individuální úrovni pro církev cestou, jak se vyrovnávat s klesající náboženskou příslušností v souvislosti s individuální rovinou sekularizačních procesů.

Změny v individuální náboženské př́íslušnosti jsou však jen jedním $\mathrm{z}$ aspektů problematiky sekularizace v moderních společnostech - nízká či klesající míra individuálně deklarované náboženské př́slušnosti ještě nemusí nutně znamenat, že náboženství výrazně mizí i z veřejné sféry. ${ }^{144} \mathrm{Na}$ societální úrovni si etablované náboženské směry a církve mohou zachovávat významnou míru přítomnosti ve veřejné sféře, například tehdy, stávají-li se témata spojená s náboženstvím předmětem debat ve veřejném prostoru, vstupují-li např́klad do oblasti politiky. Může se tak dít např́klad tehdy, když se náboženská témata s ohledem na konkrétní historické okolnosti spojila s koncepty národních dějin či národní identity a vlastenectví - $\mathrm{k}$ př́kladům takových jevů v českém prostř̀edí patří svatováclavská legenda, cyrilometodějská tradice nebo tradice husitské reformace. ${ }^{145}$ Nejen $z$ tohoto důvodu najdeme řadu př́kladů, kdy se témata spojená s církví objevují ve veřejném prostoru - diskutují se vyjádření církevních představitelů k různým událostem, ${ }^{146} \mathrm{je}$

140 Karel DOBBELAERE, Secularization, in: Encyclopedia of Religion and Society, ed. William H. SWATOS - Peter KIVISTO, London: Sage, AltaMira Press, 1998, s. 455-456.

141 Tato stat se primárně zabývá využitím internetu a online sociálních sítí v souvislosti s institucionalizovaným náboženstvím - podoby náboženského života na síti z hlediska individualizované religiozity jsou námětem pro další studium.

142 Srov. LINDEN, Global..., s. 124; srov. Christopher HELLAND, Popular Religion and the World Wide Web: A Match Made in (Cyber) Heaven, in: Religion Online. Finding Faith on the Internet, ed. Lorne L. DAWSON - Douglas E. COWAN, London: Routledge, 2004 , s. 25.

143 K náboženské situaci v české společnosti viz Dana HAMPLOVÁ, Náboženství v české společnosti na prahu 3. tísiciletí, Praha: Karolinum, 2013; k individuální úrovni sekularizace ve spojení s českou společností viz Jakub HAVLÍČEK - Dušan LUŽNÝ, Religion and Politics in the Czech Republic: The Roman Catholic Church and the State, International Journal of Social Science Studies 1/2013, s. 193-195. Srov. David VÁCLAVÍK, Katolická církev očima současných Čechů a současní Češi očima Katolické církve. Mezi nedůvěrou a očekáváním, Caritas et veritas $1 / 2016$, s. $150-156$.

144 DOBBELAERE, Secularization: An Analysis..., s. 49; srov. HAVLÍČEK - LUŽNÝ, Religion...

145 Srov. Miloš ǨEZNíK, Formování moderního národa. (Evropské „dlouhé“ 19. století), Praha: Triton, 2003, s. 146-148.

$146 \mathrm{Z}$ doby bezprostředně předcházející dokončení tohoto textu lze jako příklad uvést vyjádření kardinála Dominika Duky k reklamní kampani obchodního řetězce Lidl, kde byly vyretušovány kříže z kupolí řeckých kostelů - viz např. @ Novinky.cz, Bezprecedentní a nekulturní akt, píše Duka ke kauze vyretušovaných křížů (on-line), aktualizace dne 3. 9. 2017, dostupné na https://www.novinky.cz/ domaci/448050-bezprecedentni-a-nekulturni-akt-pise-duka-ke-kauze-vyretusovanych-krizu.html, citováno dne 19. 1. 2018. 
reflektována přítomnost státních činitelů na církevních akcích, ${ }^{147}$ církevní představitelé se účastní státních událostí1 ${ }^{148}$ atd.

V souvislosti se societální úrovní sekularizace a vstupováním náboženských témat do veřejného prostoru se mohou sociální internetové sítě stát součástí procesů nastolování agendy církví. ${ }^{149}$ Online sítě, které církev provozuje, se mohou stát platformou veřejné diskuze k tématům, která jsou pro církev důležitá. Role tzv. nových médií, k nimž se internetové sociální sítě řadí, se stávají předmětem živého zájmu řady badatelů. ${ }^{150}$ Přestože mezi badateli nepanuje shoda např́klad v tom, do jaké míry či jak samotné internetové sociální sítě ovlivňují procesy spojené s nastolováním agendy ve veřejném prostoru a jak narušují stávající modely nastolování agendy prostřednictvím klasických či tradičních médií, ${ }^{151}$ některé výzkumy důležitost internetových sociálních sítí př̀i šíření témat ve veřejném prostoru potvrzují. ${ }^{152}$

Církev využívá internet přinejmenším ve dvou základních typech či oblastech nastolování agendy: mediální a veřejné. Webové platformy církve, včetně stránek na sociálních sítích, používá církev jako zdroje informací pro novináře coby zástupce klasických médií, která mohou témata předložená církví dále šiřit. ${ }^{153}$ Církev také využívá webové platformy přímo jako prostředek šiřrení veřejné agendy spojené s řadou témat, která jsou pro církev důležitá. ${ }^{154}$ I jednoduchý přehled oficiálních sociálních sítí české katolické církve ukazuje, že jde například o oblast manželství, resp. rodinné politiky, což jsou témata, kterým se přímo věnuje jedna z tematicky specializovaných facebookových stránek.

Online sociální sítě se ve spojení jak s individuální, tak i societální úrovní také mohou stát prostř̌edkem etablování, udržování či šíření náboženské paměti. ${ }^{155}$ Kolektivní pamět, jejíž součástí je i náboženská pamět, lze chápat jako sociální konstrukt vznikající v interakci prvků sociální sítě, tedy mezi komunikujícími jednotlivci a jejich skupinami. ${ }^{156} \mathrm{Z}$ tohoto hlediska je nasnadě spojení mezi sociálními médii a náboženskou pamětí jako pamětí kolektivní. ${ }^{157}$ Technologický rozvoj v oblasti internetových sociálních sítí vede některé badatele k překročení klasické koncepce

147 Viz např. @ iDnes.cz, Jubilant Zeman vyzval po mši k návratu ke křestanským kořenům (on-line), aktualizace dne 28. 9. 2016, dostupné na https://zpravy.idnes.cz/prezident-zeman-vyzval-k-navratu-ke-krestanstvi-f6s-/domaci.aspx?c=A160928_130550_domaci_pku, citováno dne 19. 1.2018

148 @ Ondřej MLÉČKA, Kardinál Dominik Duka obdržel Řád bílého lva (on-line), aktualizace dne 28. 10. 2016, dostupné na https://www. cirkev.cz/cs/aktuality/161028kardinal-dominik-duka-obdrzel-rad-bileho-lva, citováno dne 19. 1. 2018.

149 K nastolování agendy církví v České republice viz Jan VÁNĚ - František KALVAS, Catholic Church in the Czech Republic and Public Agenda Setting: Czech Catholic Church Representatives Interviews Content Analysis, Working Papers Series 01 - 10, Plzeň: Katedra sociologie, Fakulta filozofická Západočeské univerzity, 2010; srov. Jan VÁNĚ - František KALVAS, The Agenda-Setting Effect of Focusing Events: A Case Study of the Church Restitutions Issue, Sociológia 3/2013, s. 290-315. Srov. Jan VÁNĚ, Jak/co jim říci, aby naslouchali? Aneb nastolování témat ve veřejném prostoru českou katolickou církví, Studia theologica 3/2015, s. 203-229.

150 Kritický přehled problematiky podává Jakub MACEK, Poznámky ke studiu nových médií, Brno: Masarykova univerzita, 2013.

151 Natalia ARUGUETE, The agenda setting hypothesis in the new media environment, Comunicación y sociedad 28/2017, s. 51.

152 Srov. např. Bethany A. CONWAY - Kate KENSKI - Di WANG, The Rise of Twitter in the Political Campaign: Searching for Intermedia Agenda-Setting Effects in the Presidential Primary, Journal of Computer Mediated Communication 4/2015, s. 363-380; srov. Jessica T. FEEZELL, Agenda Setting through Social Media: The Importance of Incidental News Exposure and Social Filtering in the Digital Era, Political Research Quarterly 1/2018, s. 1-13.

153 Viz např. ( ) Biskupství brněnské, Katolická církev nabízí; @ ( PRINZ, Bez Facebooku... Jan Váně a František Kalvas zjištují, že internet vnímají jako perspektivní nástroj nastolování agendy i sami církevní představitelé - viz VÁNĚ - KALVAS, Catholic Church..., s. 13, 15, 21. Srov. VÁNĚ, Jak/co jim říci..., s. 214, 223.

154 Srov. () Ondřej MLÉČKA, Představujeme nový web církev.cz (on-line), aktualizace dne 14. 3. 2016, dostupné na https://www.cirkev.cz/ cs/aktuality/160311predstavujeme-novy-web-cirkev-cz, citováno dne 19. 1. 2018.

155 S konceptem náboženské paměti pracuje Danièle HERVIEU-LÉGER, Religion as a Chain of Memory, Cambridge: Polity Press, 2000.

156 Koncept kolektivní paměti zavádí Maurice HALBWACHS, Kolektivní pamět, 2009, Praha: Sociologické nakladatelství. Př́stupy ke konceptu kulturní paměti kriticky shrnuje Dušan LUŽNÝ, Kulturní pamět jako koncept sociálních věd, Studia philosophica 2/2014, s. 3-18.

157 Srov. Joyce van de BILDT, The Uses of Facebook for Examining Collective Memory. The Emergence of Nasser Facebook Pages in Egypt, in: Memory Unbound: Tracing the Dynamics of Memory Studies, ed. Lucy BOND - Stef CRAPS - Pieter VERMEULEN, New York: Berghahn Books, 2017, s. 133. 
kolektivní paměti formované, udržované a šířené mezi jednotlivci a jejich skupinami: v prostředí sociálních sítí hovoří spiše o „konektivní paměti“, kdy digitální technologie neslouží jako pouhý prostředek či médium šíření paměti, ale „konektivní pamět“ je sociálními médii formována a strukturována v komplexní interakci lidských a technologických faktorů. ${ }^{158}$ Pro církev jsou online sociální sítě ideálním prostředkem vstupu do tohoto internetového prostředí, $v$ němž je konektivní pamět formována, udržována a šířena.

Karel Dobbelaere hovoří ještě o třetí úrovni či oblasti sekularizace, kterou je rovina organizační: v souvislosti se sociokulturními změnami spojenými se strukturální a funkcionální diferenciací v moderních společnostech se musejí měnit a přizpůsobovat i samotné církve jako organizace. Mění se nejen jejich organizační struktura, ale i doktrinální principy. ${ }^{159}$ Využívání internetu a online sociálních sítí po této stránce provázejí změny v církvi, které lze pozorovat na všech úrovních církevní správy. Papežská kurie prochází organizačními změnami, které jí dovolují efektivněji řídit oblast komunikace, včetně používání internetu a sociálních sítí, kde vznikají nové oficiální církevní platformy. Zároveň církevní autority vydávají dokumenty, které uvádějí tuto oblast do doktrinálních souvislostí - jde o dokumenty různého typu, od papežských listů až po dokumenty vydané př́slušnými kuriálními úřady a jejich představiteli. Organizační změny související s využíváním internetu a online sociálních sítí se projevují i na nižších úrovních církevní správy, kdy např́iklad při arcibiskupství a biskupství existují zvláštní oddělení se zaměstnanci, kteří mají tuto oblast komunikace na starosti. ${ }^{160}$

\section{Závěrem}

Česká katolická církev je na nejvyšších úrovních církevní správy na sociálních sítích zastoupena oficiálními stránkami všech biskupství a pražského arcibiskupství. Pouze olomoucké arcibiskupství oficiální stránku na sociálních sítích nemá. Aktivity pražského arcibiskupství, zejména jeho Pastoračního střediska, jsou ve srovnání s aktivitami ostatních biskupství na sociálních sítích velmi výrazné a co do tematického zaměření diverzifikované. $Z$ hlediska tematického zaměření jsou tyto stránky orientovány na práci s mládeží a na oblast evangelizace a pastorace, zvláště ve spojení s tématy, která jsou pro církev důležitá - např́ílad ve spojení s tematikou manželství. Zastoupení představitelů vysokého kléru na sociálních sítích je spíše výjimkou. Celkově je sledovanost oficiálních církevních stránek spíše nižší a lze vyslovit domněnku, že online sociální sítě představují pro českou katolickou církev doposud ne zcela využitý prostor, do něhož se však církev pokouší systematicky proniknout - to je patrné např́íklad z aktivit Arcibiskupství pražského.

Z emického hlediska deklaruje církev dvě základní funkce webových prezentací a prezentací na sociálních sítích. Informační funkce spočívá v informování veřejnosti o různých aktivitách církve a v prezentování postojů církve $\mathrm{k}$ aktuálním událostem a problémům. Evangelizační a pastorační funkce spočívají ve využití sociálních médií jako prostředku k prezentaci a propagaci křestanského (katolického) světonázoru. Lze se setkat i s názory, že internet a sociální sítě nejsou pouhým nástrojem, ale i samotným cílem evangelizačního působení. $V$ této rovině souvisí používání sociálních sítí s konceptem nové evangelizace, která je chápána nejen v klasickém významu

158 Viz José van DIJCK, Flickr and the culture of connectivity: Sharing views, experiences, memories, Memory Studies 4/2010, s. 401-415; Andrew HOSKINS, Digital Network Memory, in: Mediation, Remediation, and the Dynamics of Cultural Memory, ed. Astrid ERLL - Ann RIGNEY, Berlin: de Gruyter, 2009, s. 91-106; Andrew HOSKINS, 7/7 and connective memory: Interactional trajectories of remembering in post-scarcity culture, Memory Studies 3/2011, s. 269-280.

159 Viz DOBBELAERE, Secularization: An Analysis..., s. 105.

160 Viz např. () Arcibiskupství pražské, Organizační řád Arcibiskupství pražského (on-line), s. 14-15, 17, dostupné z http://www.apha.cz/ file/74649/organizacni-rad-17296-r-2016-elektr.pdf, citováno dne 19. 1. 2018. 
re-evangelizace, ale i jako evangelizace za pomoci nových technologických prostředků.

V etické perspektivě, $\mathrm{z}$ hlediska religionistiky, lze využití online sociálních sítí uvést do souvislosti s konceptem sekularizace. Tuto problematiku je z koncepčního hlediska vhodné rozčlenit na tř̌i základní úrovně: individuální, societální a organizační, aniž by bylo možné jednotlivé složky sekularizačních procesů na těchto úrovních popisovat a analyzovat jako vzájemně nesouvisející. V individuální rovině jsou sociální sítě pro církev prostř̌edkem a zároveň prostředím, kde církev může provádět šiření náboženského světonázoru v nejširších souvislostech. Využití nových komunikačních platforem s jednotlivci - členy online sociálních sítí - se pro církev stává způsobem vyrovnávání se se sekularizací v individuální rovině, je reakcí církve na procesy privatizace a individualizace náboženství.

V societální rovině zapojuje církev sociální sítě do procesů nastolování agendy, zejména na mediální a společenské veřejné úrovni. Zároveň jsou sociální sítě pro církev prostředkem vytváření, udržování a širrení náboženské paměti ve specifické formě „konektivní paměti“ spojené právě s online sociálními sítěmi, což lze vztahovat jak k societální, tak k individuální úrovni sekularizace.

Konečně v organizační rovině církev nepřizpůsobuje měnící se sociokulturní situaci jen svou vlastní organizační strukturu, ale spolu s novými způsoby komunikace a šíření informací pomocí nových technologií přizpůsobuje nové situaci i doktrinální stránku.

Základní záměr této studie nespočívá $\mathrm{v}$ definitivním zhodnocení tematiky prezentace církve na internetu a sociálních sítích. Závěry, které přináší, jsou v mnoha ohledech vlastně jen náznakem směru dalšího bádání či podnětem pro potenciální kritické přehodnocení. Lze se domnívat, že do budoucna bude prezentace prostřednictvím internetu a online sociálních sítí mít vzrůstající význam pro veřejně působící činitele, $\mathrm{k}$ nimž lze řadit i katolickou církev a její představitele. Pro sociální vědy půjde o podnětné téma, které bude bezpochyby vyžadovat nové př́stupy, a to jak po stránce teoretické, tak metodologické.

\section{Kontakt}

Mgr. Jakub Havlíček, Ph.D.

Univerzita Palackého v Olomouci

Filozofická fakulta, Katedra sociologie, andragogiky a kulturní antropologie

trída Svobody 26, 77900 Olomouc

jakub.havlicek@upol.cz 